\title{
The Polypeptide Composition of Avian Infectious Bronchitis Virus
}

\author{
By \\ R. W. BINGHAM \\ Division of Communicable Diseases, Clinical Research Centre, \\ Harrow, Middlesex, England \\ With 3 Figures \\ Accepted July 23, 1975
}

\begin{abstract}
Summary
Avian infectious bronchitis virus grown in ovo was purified by differential centrifugation and isopycnic sedimentation in density gradients. The purified virus was analysed by SDS polyacrylamide gel electrophoresis and found to comprise up to sixteen polypeptides, four of which were glycopeptides. Bromelain treatment of the particles removed three polypeptides and two glycopeptides.
\end{abstract}

\section{Introduction}

The coronaviruses have been classified as a separate virus group mainly on the basis of their distinctive morphology (12). There have been many studies [reviewed by McINTosh (7)] demonstrating that the growth of these viruses is insensitive to inhibitors of DNA metabolism or DNA dependent RNA synthesis. For this reason the nature of the coronavirus genome has been assumed to be RNA. However, there have been few reports of the results of direct chemical analyses of the virion. There have been two reports $(10,14)$ of extraction and analysis of nucleic acid from purified virions of avian infectious bronchitis virus (IBV) and these indicated that the virus contains RNA. It has also been deduced from the appearance of the particles, the sensitivity of infectivity to ether and chloroform, and the mode of development of particles observed in thin sections of infected cells, that they contain lipid derived from the host as an integral part of the outer shell. However, there are no reports on extraction and analysis of lipids from purified particles. Although there are at least seven different species in the coronavirus genus (7), only one type, the human coronavirus OC43, has been subjected to eleotrophoretic analysis of the polypeptides (5). This report describes preliminary biochemical investigations of another coronavirus, avian infectious bronchitis virus. 


\section{Materials and Methods}

\section{Virus Strains}

IBV strain Beaudette (IBV-42) was obtained from Mr. J. S. MeDougall, Houghton Poultry Research Station, Huntingdon; IBV strain Massachusetts (IBV-41) from Mr. T. Hall, Wellcome Research Laboratories, Beckenham; IBV strain Connecticut (IBV-46) from Dr. S. Reed, MRC Common Cold Unit, Salisbury and IBV-H120 (a Massachusetts serotype) from the commercially available live vaccine, Bronvirin (Glaxo Ltd.). Each of these stocks had a long history of passage in embryonated chicken eggs before their receipt in this laboratory.

\section{Cell Cultures and Infectivity Assays}

Primary chicken kidney cell cultures were used for production or infectivity assays of IBV. The kidneys from 3-7 week old specific-pathogen-free chickens (Wickham Laboratories Ltd., Wickham, Hampshire) were dispersed by serial 5 minutes incubations at $37^{\circ} \mathrm{C}$ in 0.05 per cent trypsin (Difco Laboratories) in phosphate buffered saline (PBSA: Dulbecco's type A, Oxoid Ltd.). The cells obtained were strained through nylon mesh and dispensed either in Eagle's Medium Basal (BME: Wellcome Reagents Ltd.) or in L-15 medium (Gibco), both media being supplemented with 8 per cent foetal calf serum, 4 per cent tryptose phosphate broth, $100 \mathrm{units} / \mathrm{ml}$ penicillin and $100 \mu \mathrm{g} / \mathrm{ml}$ streptomycin. The BME was used for cells grown in vented plastic dishes in a 5 per cent $\mathrm{CO}_{2}$ atmosphere, the $\mathrm{L}-15$ used for growth of cells in closed glass bottles or tubes. For the growth of virus, confluent cell cultures were changed into maintenance medium, which was similar in composition to the growth medium but without the foetal calf serum. Estimations of virus infectivity were made by inoculating $0.2 \mathrm{ml}$ aliquots of appropriate dilutions of virus into rolling tube cultures already containing $1 \mathrm{ml}$ of maintenance medium. Cytopathic effects on the cells were observed at 48 hours (strain Beaudette) or 72 hours (strain Massachusetts 41 and Connecticut) after inoculation, and infectivity measurements experssed as $\mathrm{TCD}_{50} / 0.2 \mathrm{ml}$. IBV. $\mathrm{H} 120$ caused no distinct cytopathic effect and was not used in experiments requiring infectivity measurements. IBV-Beaudette could also be estimated by plaque formation assays, but this method was not routinely used. All cell culture and virus growth was performed at $37^{\circ} \mathrm{C}$.

\section{Growth and Purification of Virus}

Usually $10^{4}-10^{5} \mathrm{TCD}_{50}$ of virus was inoculated (in $0.05-0.2 \mathrm{ml}$ ) into the allantoic cavity of 10-day old embryonated chicken eggs (Orchards Farm, Gt. Missenden, Bucks) and incubated at $37^{\circ} \mathrm{C}$ for 24 hours. After chilling at $4^{\circ} \mathrm{C}$ overnight the allantoic fluid was harvested and immediately clarified by centrifugation at $16,000 \mathrm{~g}$ for 20 minutes. This and all subsequent operations were carried out at $0^{\circ}-4^{\circ} \mathrm{C}$. The virus was pelleted at $75,000 \mathrm{~g}$ for 1 hour in a MSE No. 59595 rotor and resuspended in PBSA with the aid of a glass Dounce homogeniser. The resuspended virus was overlaid on a linear 25 to 55 per cent sucrose (w/w) in PBSA gradient and centrifuged overnight (12-16 hours) in a MSE No. 59590 rotor at $90,000 g$. The virus bands were collected, diluted 8-fold in PBSA and repelleted at $75,000 \mathrm{~g}$ for 1 hour. The pellets were resuspended in the same manner as before and layered on either (a) a linear $25-55$ per cent sucrose $(\mathrm{w} / \mathrm{w})$ in PBSA gradient, or (b) a linear $25-55$ per cent potassium sodium tartrate $(\mathrm{w} / \mathrm{w})$ in PBSA gradient and centrifuged overnight at $60,000 \mathrm{~g}$ in a MSE No. 59108 rotor.

\section{Polyacrylamide Gel Electrophoresis (PAGE) of Virus Polypeptides}

Purified virus collected from the second gradient step was diluted in PBSA, deposited at $75,000 \mathrm{~g}$ for 1 hour and dissolved in a small volume of 5 per cent sodium dodecyl sulphate (SDS) at $37^{\circ} \mathrm{C}$ for 30 minutes. 2-mercaptoethanol was added to a final concentration of 2 per cent and the solution incubated in a boiling water bath for 2 minutes. The dissolved virus was dialysed overnight at room temperature against $5 \mathrm{~mm}$ Tris, $38 \mathrm{~mm}$ glyoine buffer ( $\mathrm{pH} 8.3$ ) containing 1.0 per cent SDS, 0.1 per cent 2-mercaptoethanol, $3.3 \mathrm{M}$ Urea and 5 per cent sucrose. After dialysis a trace amount of bromophenol blue was added and the sample reheated at $100^{\circ} \mathrm{C}$ for 1 minute immediately prior to electrophoresis. 
Electrophoresis was carried out on cylindrical polyacrylamide gels $12 \mathrm{~cm} \times 0.65 \mathrm{~cm}$ diameter, cast in perspex tubes. The acrylamide concentration was $10,7.5$ or 5 per cent $(\mathrm{w} / \mathrm{v})$, the acrylamide: bis-acrylamide ratio being constant at $37.5: 1$ by weight. The gels also contained 0.1 per cent SDS, $0.5 \mathrm{M}$ urea, 0.03 per cent $\mathrm{N}, \mathrm{N}, \mathrm{N}^{\prime}, \mathrm{N}^{\prime}$ - tetramethylethylenediamine, 0.07 per cent ammonium persulphate and 0.375 м TrisHCl buffer, $p H$ 8.9. Gels were pre-electrophoresed at $100 \mathrm{~V}$ for $1 \frac{1 / 2}{2} 2$ hours, the electrophoresis buffer consisting of $25 \mathrm{mM}$ Tris, $192 \mathrm{~mm}$ glyeine, 0.1 per cent SDS, $0.5 \mathrm{M}$ urea, 0.1 per cent 2-mercaptoacetic acid, $\mathrm{pH}$ 7.8. If non-reducing conditions were required, the 2-mercaptoacetic acid was omitted-the buffer then being $\mathrm{pH} 8.3$ and reductant omitted during preparation of the sample. After pre-electrophoresis the sample was layered directly on the top of the gel in not more than $200 \mu$ l volume, and electrophoresis carried out at $100 \mathrm{~V}$ for $4-8$ hours. In some experiments the system described by WEBER and OsBorN (15), with phosphate buffer $\mathrm{pH} 7.0$, was used. After electrophoresis gels were stained for protein (9) or carbohydrate (16). The molecular weights of viral peptides were determined by reference to the mobilities of $\beta$-galaetosidase, phosphorylase A, transferrin, bovine serum albumin, pyruvate kinase, ovalbumin, alcohol dehydrogenase (yeast), myoglobin and lysozymo in control gels.

\section{Chemical Determinations on Purified Virus}

Fractions from gradients were exhaustively dialysed against distilled water to remove the sucrose or tartrate gradient material. Concomitant changes in volume during dialysis were noted. Estimations were carried out for RNA (8), protein (6), DNA (2) and carbohydrate (4). Alternatively protein and RNA were estimated from the extinctions at 260 and $280 \mathrm{~nm}\left(\mathrm{E}_{260}\right.$ and $\left.\mathrm{E}_{280}\right)$ (13).

\section{Bromelain Treatment of Virus Preparations}

IBV from the first sucrose gradient stage of the purification was incubated with bromelain (Sigma Chemical Co.) (3). After incubation, the mixture of virus and enzyme was diluted in ice-cold PBSA, pelleted, resuspended and centrifuged on a second sucrose gradient as described above.

\section{Fesults}

\section{Purification of Virus}

On the first sucrose gradient stage the virus formed two distinct bands, Table 1 indicates the buoyant densities of the different strains. The two bands were put on separate gradients for the second stage of the purification, and they retained their original density as a single band. The various bands from both gradient stages were negatively stained in sodium phosphotungstate and examined with the electron microscope by Dr. J. D. Almeida, Wellcome Research Laboratories, and were found to contain intact virus; there was no detectable difference between the light and heavy forms. A small proportion of the virus particles became degraded on tartrate gradients, so in subsequent purifications the tartrate was replaced by a second sucrose gradient. The infectivity of the purified virus fractions was measured, and a typical result is presented in Table 2. It can be seen that both the light and heavy forms of the virus were infectious, although the heavy band was significantly more infectious with respect to protein and nucleic acid. The second gradient step appears to have caused a loss of infectivity of the heavy form, and a reduced RNA: protein ratio of that band, suggesting a partial loss of nucleic acid.

It was thought that the virus might be contaminated by mycoplasmas, which are often present in hens eggs and which may be of similar size and density (11). The infected allantoic fluids were therefore tested for viable mycoplasmas by 
Miss Patricia M. Furr of this Institute but the results were negative. Purified IBV preparations were tested for avian leukosis virus (ALV) by Mr. T. Webster, Wellcome Research Laboratories, using the complement fixation test (COFAL) and these were also negative. No particles resembling mycoplasmas, ALV or any other virus were ever seen in any of the electron microscopic examinations of purified virus.

Table 1. Buoyant densities of different strains of IBV on sucrose gradients

\begin{tabular}{llll}
\hline Strain & $\begin{array}{l}\text { Mean density of } \\
\text { light band }\end{array}$ & $\begin{array}{l}\text { Mean density of } \\
\text { heavy band }\end{array}$ & $\begin{array}{l}\text { Number of } \\
\text { experiments }\end{array}$ \\
\hline Connecticut & 1.18 & 1.22 & 3 \\
Beaudette & $(1.178-1.182)^{\mathrm{a}}$ & $(1.217-1.223)^{\mathrm{a}}$ & \\
& 1.18 & 1.22 & 5 \\
Massachusetts & $(1.179-1.183)^{\mathrm{a}}$ & $(1.219-1.223)^{\mathrm{a}}$ & \\
& 1.175 & 1.21 & 2 \\
H 120 & 1.16 & $(1.210 \& 1.213)^{\mathrm{a}}$ & \\
& $(1.159 \& 1.160)^{\mathrm{a}}$ & $(1.180 \& 1.184)^{\mathrm{a}}$ & 2 \\
\hline
\end{tabular}

2 Maximum and minimum values obtained.

Table 2. Infectivity of IBV-Beaudette fractions recovered from gradients

\begin{tabular}{|c|c|c|c|c|}
\hline Fraction & & $\begin{array}{l}\log _{10} \mathrm{TCD}_{50} / \mathrm{mg} \\
\text { protein }^{\mathrm{a}}\end{array}$ & $\begin{array}{l}\log _{10} \mathrm{TCD}_{50} / \mathrm{mg} \\
\mathrm{RNA}^{\mathrm{a}}\end{array}$ & $\begin{array}{l}\text { RNA : protein } \\
\text { ratio }^{\text {b }}\end{array}$ \\
\hline Light band & 1st sucrose & 5.1 & 6.3 & 0.069 \\
\hline Heavy band $\}$ & sucrose gradient & 5.9 & 7.1 & 0.059 \\
\hline Light band | & 2nd tartrate & 5.0 & 6.3 & 0.052 \\
\hline Heavy band & gradiento & 5.2 & 6.7 & 0.036 \\
\hline
\end{tabular}

a $\log _{10} \mathrm{TCD}_{50}$ measurements subject to $\pm 0.3 \log _{10} \mathrm{TCD} / 0.2 \mathrm{ml}$ error.

b Estimated from $\mathrm{E}_{260} / \mathrm{E}_{280}$ ratio (13).

c Material from 1st sucrose gradient after rebanding on tartrate gradient.

\section{Chemical Characterisation of Purified Virus}

It was not possible to obtain sufficient purified virus to make a complete analysis of nucleic acid, protein, carbohydrate and lipid content and relate this to the dry weight of virus material. However, it was possible to make some chemical determinations and relate these to the protein content of the particles. The RNA: protein ratio ranged from $0.71-0.84$ (5 batches of virus) when measured by chemical means $(8,6)$-on measurement by extinctions, the ratios ranged from $0.036-0.069$ (9 batches of virus), the average being 0.054 . The amounts of RNA determined by the two methods were in very close agreement. The discrepancy in the RNA: protein ratio arises from the very different results obtained from the two methods for protein estimation. As the method of Lowny et al. (6) is rather sensitive to interference by a variety of compounds, including sugars, it is possible that the viral nucleic acid, carbohydrate and lipid have caused sufficient interference to render the result from this method invalid. The carbo- 
hydrate: protein ratio ranged from $0.11-0.22$ (3 batches of virus) - the protein being estimated by $\mathbf{E}_{260} / \mathbf{E}_{280}$ measurements. The carbohydrate values were corrected for the RNA content of the preparations. Attempts were also made to detect the presence of DNA in purified virus. Although trace levels were detected, these levels were within the calculated levels of interference in the diphenylamine test by the viral RNA present. It was concluded that there was probably no genuine DNA in the preparations.

These results are the first direct chemical confirmation that the virion nucleic acid is indeed RNA, and also that the particles contain carbohydrate in addition to the nucleic acid and protein. Other experiments in progress in this laboratory (S. Johnson and R. W. Bingmam - unpublished results) have confirmed the presence of various lipids in purified preparations of the virus.

\section{$P A G E$ of Purified Virus}

Initial experiments using the Tris-glycine buffered electrophoresis system gave much better resolution of the IBV polypeptides than that achieved with the phosphate system (Fig. 1) - some of the bands visible in the former did not appear

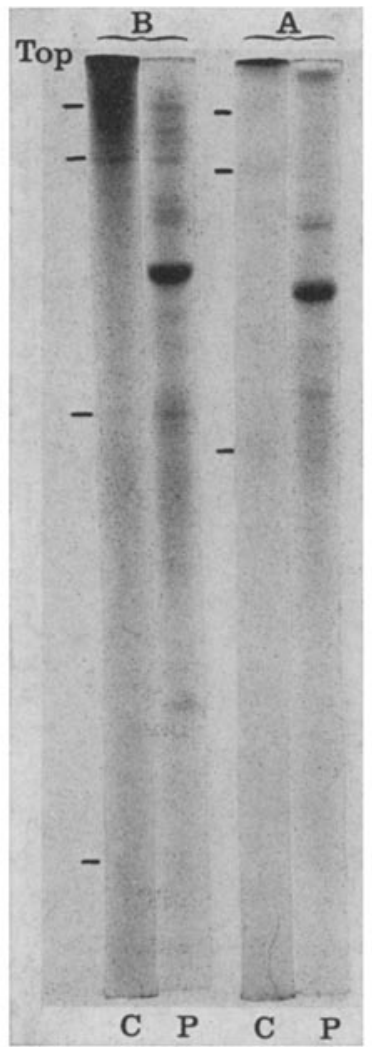

Fig. 1. PAGE of IBV. A. phosphate buffer system, B. tris-glyoine buffer system, 10 per cent acrylamide in both systems, identical samples loaded on all four gels. P. stained for protein, C. stained for carbohydrate. As the photographic process did not record the red bands as clearly as the blue, the positions of the carbohydrate bands seen with the naked eye have been marked alongside the appropriate gels 
at all in the latter. Therefore all subsequent experiments were done by the former method. Figure 2 illustrates typical densitometer tracings (made with a JoyceLoebl Chromoscan) of gels which have been stained for either protein or carbohydrate. There are up to sixteen peptides present, three or four of which appear to be glycosylated. Although the profiles of the light and heavy forms appear to be dissimilar (Fig. $3 \mathrm{a}, \mathrm{b}$ ), it may be seen that the same peptides are present in both, and only the relative proportions differ. Examinations of many such profiles showed that this was a reproducible phenomenon. No significant difference between strains was detected. Numbers were assigned to the peptides on the basis of their molecular weights to assist in comparison of profiles. The molecular weights determined from twelve experiments are listed in Table 3 . When the separated light and heavy forms of the virus were treated with bromelain and recentrifuged on sucrose gradients, it was found that both forms yielded identical single bands of virus at a new lighter density of 1.15. These treated particles were examined by electron microscopy (by Dr. S. Patterson of this Institute) and were almost totally lacking in projections. PAGE profiles of the virus before and after treatment are illustrated in Figure 3 . It can be seen that the bromelain removed

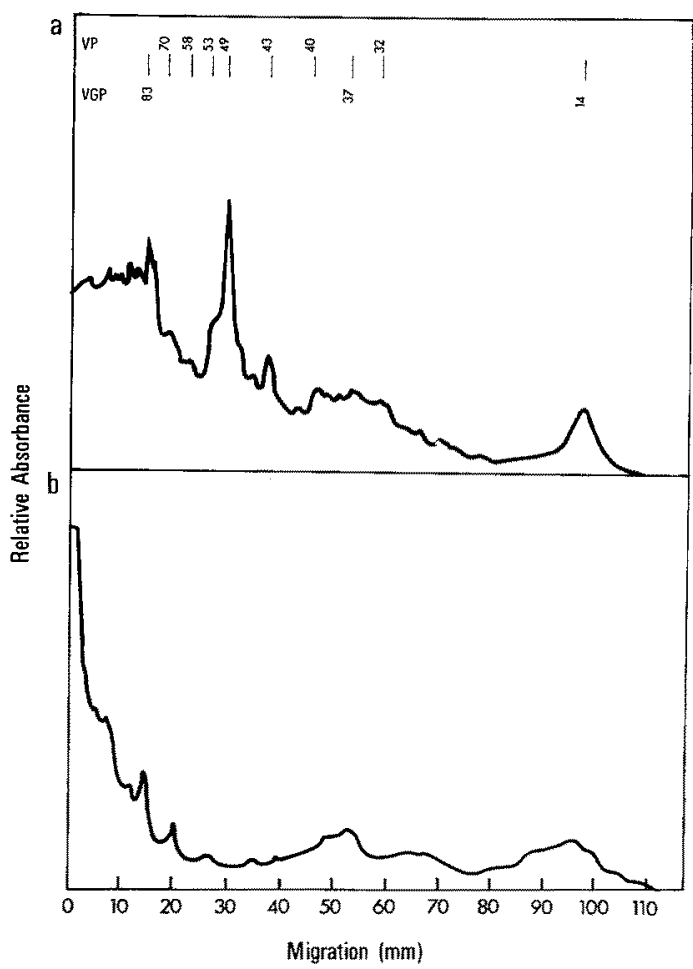

Fig. 2. Densitometer tracings of PAGE of IBV (strain Beaudette, heavy form) on 10 per cent acrylamide gels (tris-glycine buffer system). a) gel stained with Coomassie Brilliant Blue for peptides; b) gel stained with periodate and Schiff's reagent (PAS) for carbohydrate. Gels run for $51 / 2$ hours. Only those bands consistently found in every preparation have been labelled VP or VGP. Occasionally VP 70 showed slight staining with PAS as seen here, but this was not reproducible 
two of the glycopeptides (VGP180 and VGP83) and substantially reduced the proportions of VP130, VP106 and VP70. As VP 53 and VP49 usually tend to run as an overlapping pair, it is not possible to say whether any VP53 remains. The relative proportions of the lower molecular weight peptides have considerably increased in relation to the prominent VP 49. Three new peptides, designated XP27, XP20 and XP18 (27,000, 20,000 and 18,000 daltons respectively) have also appeared in the profile. It seems likely that these are cleavage products of some of the larger peptides, rather than contamination with the bromelain; when brome-

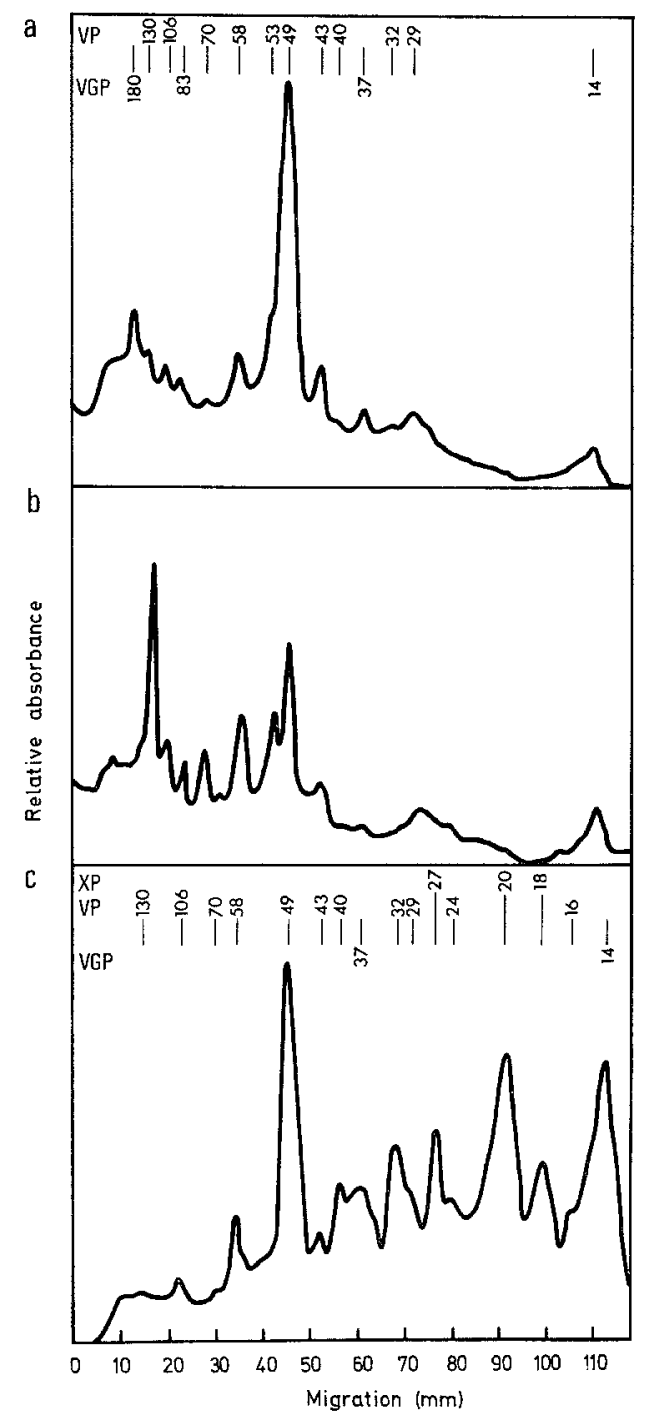

Fig. 3. Densitometer tracings of PAGE of IBV (strain H 120) on 10 per cent acrylamide gels (tris-glycine buffer system), stained with Coomassie Brilliant Blue. a) light form of virus (1.16 density); b) heavy form (1.18 density); c) bromelain treated (light form; heavy form gave identical pattern). Gels run for 6 hours 
lain was electrophoresed in a parallel gel it gave several peaks, none of which coincided with the new peptides. Also it was calculated that about 90 per cent of the added bromelain would have had to remain adhering to the virus through the purification steps after incubation in order to yield the amounts detected of the new peptides. These results suggest that VGP180, VP130, VP106, VGP83 and VP70 are accessible on the surface of the virion, the remaining peptides presumably being internal.

Newcastle Disease virus (strain Herts) and influenza virus (strain X31) were grown in ovo, purified by exactly the same techniques and electrophoresed in parallel to the IBV preparations. Only the typical peptide bands of those viruses were detected, and there were no bands corresponding to any of the bands located in the IBV samples. This was evidence that the purification scheme used was adequate for isolating pure specimens of other enveloped viruses of similar size, density and origin to IBV without host component contamination.

Table 3. Molecular weights of polypeptides of IBV

\begin{tabular}{lcc}
\hline Peptide number & $\begin{array}{l}\text { Mean } \\
\text { molecular weight } \\
\times 10^{-3}\end{array}$ & $\begin{array}{l}\text { Lowest and highest } \\
\text { values obtained } \\
\times 10^{-3}\end{array}$ \\
\hline VGP 180 & 180 & $176-185$ \\
VG 130 & 130 & $127-135$ \\
VP 106 & 106 & $96-119$ \\
VGP 83 & 83 & $79-90$ \\
VP 70 & 70 & $68-72$ \\
VP 58 & 58 & $52-62$ \\
VP 53 & 53 & $50-54$ \\
VP 49 & 49 & $45-52$ \\
VP 43 & 43 & $42-45$ \\
VP 40 & 40 & $39-41$ \\
VGP 37 & 37 & $37-38$ \\
VP 32 & 32 & $27-30$ \\
VP 29 & 29 & $22-25$ \\
VP 24 & 24 & $15-18$ \\
VP 16 & 16 & $12-15$ \\
VGP 14 & 14 & \\
\hline
\end{tabular}

* VP virion peptide; VGP virion glycopeptide.

b Results from 12 experiments.

\section{Discussion}

The prime question which arises when considering the observed polypeptide composition of any virus is that of the purity of the preparation. This is especially important when there are apparently a large number of peptides present, as in this case. The four main contaminants that may arise in purified preparations of most animal viruses are host cellular components, endogenous virus from those cells, mycoplasmas and bacteria. The second and third possibilities have been tested for and excluded in this case, and the fourth would have been very obvious in electron microscopic examination. Also any significant level of bacterial or mycoplasmal 
contamination would have resulted in readily detectable quantities of DNA in the preparations. This leaves the problem of possible contamination by host cellular peptides. It is difficult to differentiate between host material that is an integral part of the virion and that which may have remained associated with the preparation through the various stages of the purification. One approach to the problem would be a comparison of virus grown in different cell types on the assumption that the peptides contributed by the host would differ in the various preparations. However, this would not resolve the question of whether it was an integral part of, or merely associated with, the virion. This is not possible with IBV anyway, due to the very restricted selection of cells in which it may be grown - the strains used here were only capable of culture in ovo or in primary chicken kidney cells. In the samples of purified virus used here, there were no major contaminants visible by electron microscopy. Although there were occasional pieces of membrane, some clearly deriving from disintegrating virions, the relative amounts of virus particles and possible host components were such that any contribution of the latter to the analysis would have been negligible. In some preparations examined there was a "contamination" by detached viral projections, mainly in the heavy band - as the amounts of these present varied from sample to sample, this could account for the difference in the relative proportions of the polypeptides observed in the light and heavy forms. This leaves the possibility that host polypeptides may be an integral part of the virion. It has been shown (1) that when IBV was treated with unheated rabbit antiserum raised against normal chicken cell membranes, holes appeared in the virus envelope, similar to those produced using rabbit antiserum raised against the virus itself. Use of chicken antiserum did not cause these holes. This suggested that host components were an essential part of the virus envelope.

A recent report (14) describes the RNA content of the virus as being in one ribonuclease sensitive piece, of molecular weight $9 \times 10^{6}$ daltons. If this represents the size of the IBV genome, then the virus would contain adequate coding capacity to account for all the peptides observed, assuming they are all independently coded and some are not cleavage products of others, eliminating the necessity to postulate the presence of peptides of cellular origin.

It is of interest to compare these results with the report on the polypeptides of the human coronavirus OC43 (5). Although those authors only claim the presence of six or possibly seven polypeptides, examination of their gel tracings shows the presence of several more minor bands. Also, they used a phosphate buffered pH 7.2 PAGE system very similar to that which gave comparatively poor resolution with IBV. Thus the avian and human coronaviruses may not be as dissimilar as is at first apparent.

\section{Acknowledgments}

I wish to thank Mrs. Christine Fry and Miss Hilary Madge for their valuable technical assistance, Dr. S. Patterson, for some of the electron microscopy, and Mr. T. Hall, Mr. T. Webster and Dr. June D. Almeida of Welleome Research Laboratories, Beckenham, for much invaluable advice and assistance, especially with establishing the tissue culture system (T. H. \& T. W.) and the electron microscopy (J. D. A.). I am indebted to Dr. D. A. J. Tyrrell for his advice and encouragement throughout these studies. 


\section{References}

1. BerRy, D. M., ALmeIDA, J. D.: The morphological and biological effects of various antisera on avian infectious bronchitis virus. J. gen. Virol. 3, 97-102 (1968).

2. BuRton, K.: A study of the conditions and mechanisms of the diphenylamine reaction for the colorimetric estimation of deoxyribonucleic acid. Biochem. J. $62,315-323(1956)$.

3. Compans, R. W., Krenk, H. D., Caligurar, L. A., Choppin, P. W. : Influenza virus proteins. I. Analysis of polypeptides of the virion and identification of spike glycoproteins. Virology 42, 880-889 (1970).

4. Dubors, M., Grules, K. A., Hammton, J. K., Rebers, P. A., Smmth, F.: Colorimetric method for determination of sugars and related substances. Anal. Chem. 28, 350-356 (1956).

5. Hiermolzer, J. C., Palmer, E. L., Whitfield, S. G., Kaye, H. S., Dowde, W. R.: Protein composition of coronavirus OC 43. Virology 48, 516-527 (1972).

6. Lowry, O. H., Rosebrough, N. J., FarR, A. L., Randall, R. J.: Protein measurement with the Folin phenol reagent. J. biol. Chem. 193, 265-275 (1951).

7. MoIntosh, K.: Coronaviruses: a comparative review. Current Topics in Mirobiology and Immunology 63, 85-129 (1974).

8. MejBAUM, W.: The determination of small amounts of pentose, especially in adrenal acid derivates. Hoppe-Seyler's Z. physiol. Chem. 258, 117-120 (1939).

9. Moore, N. F., Kedxy, D. C.: Sendai virus structural proteins: analysis of polypeptides linked with disulphide bonds. Intervirology 2, 128-133 (1973/74).

10. Tannock, G. A.: The nucleic acid of infectious bronchitis virus. Arch. ges. Virusforsch. 43, 259-271 (1973).

11. Taylor-Robinson, D.: Personal communication (1973).

12. Tyrret, D. A. J., Almeida, J. D., Berry, D. M., Cunninghay, C. H., Hamre, D., Hofstad, M. S., Malduci, L., McIntosh, K.: Coronaviruses. Nature, Lond. 220, 650 (1968).

13. Warbure, O., Christran, W.: Isolierung und Kristallisation des Gärungsferments Enolase. Biochem. Z. 310, 384-421 (1941).

14. Watkins, H., Reeve, P., Alexander, D. J.: The ribonucleic acid of infectious bronchitis virus. Archives of Virology 47, 279-288 (1975).

15. WeBer, K., OsвoRN, M.: The reliability of molecular weight determinations by dodecyl sulphate-- polyacrylamide gel electrophoresis. J. biol. Chem. 244, 4406 $-4412(1960)$.

16. Zacharius, R. M., Zele, T. F., Morrison, J. H., Woodlock, J. J.: Glyeoprotein staining following electrophoresis on acrylamide gels. Anal. Biochem. 30, 148-152 (1969).

Author's present address: Dr. R. W. Bingham, Department of Veterinary Pathol ogy, Royal (Dick) School of Veterinary Studies, Edinburgh, EH9 1QH, Scotland.

Received April 28, 1975 